\title{
Perception of Thai Students about Graduate Business Program: Comparison between Online and On- Campus Program
}

\author{
Thanisorn Rojanadilok, Viroj Daraviroj \\ Huachiew chalermprakiet University, Thailand \\ daradaraviroj28@gmail.com
}

\begin{abstract}
This study was an investigation of the perception of Thai students on graduate business program comparison between Online and On-Campus program. The graduate business program appropriate with people who seek to advance your current position, growth your career, the source of competitive advantage, develop the business knowledge, development yourself, increase management skill, and start students' own business. The qualitative research by in-depth interview of thirty students who want to study in graduate business in the comparison between Online and On-Campus program. The question was an interview about the benefit of Online and On-Campus business program, the disadvantage of Online and On-Campus business program, the balancing of learning, working, life balance, the advance on job career of Online and On-Campus business program. The Online business program, students, can balance the learning, and work responsibility because of the graduate business program available to students 24 hours in 7 days in everywhere your convenience. The students can schedule, ask the question a one- on one meeting discussion between students, and professor. The Online program is not disrupting work, your hobby, and daily family life. The online graduate business program appropriates with people who seek to growth, your career and develop the business knowledge. The On-Campus program has a strong relationship, the connection among students more than the online graduate business program. Students can interact with friends and professor. On-Campus enhances the leadership of the students and quantitative skill. The student has alumni, and community in the building. On-Campus graduate business program appropriate with people who seek to advance your current position source of competitive advantage, increase management skill start students' own business because program give the educational experience, and communication skill.
\end{abstract}

Keywords: Perception, online graduate business program, on-campus graduate business program.

\section{Introduction}

Objectives of this study to compare Thai students perception between On-campus and Online graduate business program, and find out the benefit and advantage of On-campus Online graduate business programs of Thai students. The On-Campus and Online business graduate programs are the qualifications for a supervisor to advanced to manager, give your opportunities for a salary increase. Students have decision making to apply Online or On-Campus program depend on various reasons.

- The degree of designation. The degree is the most important for students who seek to advance the job and increase salary.

- Cost of the program. The students compare the cost between Online and On-Campus before deciding to apply for the program.

- Difficulty of On-Campus, and Online graduate business program.

- Library services for students On-Campus and Online program.

- The Value of networking among students, alumni compare between Online and On-campus business program.

Objective: To study the perception of Thai students between Online and On-Campus graduate business program in Thailand.

\section{Review of Literature}

Maija et al. (2016) study that the international massive open online course (MOOC) was experienced to be relevant following reasons: good content, implementation of course, the course makes it possible to study in a new way, and the personally useful. The characteristics of the MOOC, such as being available anywhere, 
anytime, free access, online learning, bringing out a flexible new way of learning. Miri et al. (2016) study that both On-Campus and Online students maintained that successful online learning relies on cognitive strategies, and regulation of cognition (a metacognitive skill). Online students indicated the skills, such as planning, thinking, and evaluation. On-Campus students must have self-responsibility.

Muqiang et al. (2018) study show that the students maintain the best learning achievement by using a costefficient technique that encourages students to receive knowledge without On-Campus limitation. More importantly, compared with the On-Campus lecture-based course category, the Online and On-campus course significantly improved the students' knowledge, and hard skill. Ismail \& Omer (2014) study that the new technologies in the electronic learning such as Web-based Instruction, Online learning, and Internet-based instructionuse human-computer interaction activities for designing visuals ,text, and student design to develop future electronic learning course. Simin et al. (2014) study that the rapid growth of Information and Communications Technology (ICT) has become one of the most important topics the ICT provide proactive teaching, hard skill and learning environment. The present digital period, lecturer want to integrate ICT in their teaching, use modern equipment, and facilities. Peter (2017) study that deep learning were developed several innovative teaching strategies delivered in Research methods to graduate business students.

Blog, interactive tutorials, online videos, games, and posters are used to develop a student's cognitive abilities. Shu-Man et al. (2014) told that the potential of promoting student use the online social network. Online social networks changed the ways students manage their social relationships social network activities such as checking Facebook post and the potential to assist students' development. Elena \& Ioana (2015) study that Facebook is given the uncensored post their interests, preferences, goals, and expectations. As a social networking site, Facebook is particularly used for reasons related to social documentation (social searching) maintain the relationship among friends, and initiate new contacts. Mohsen \& Fatemeh (2014) told that social networks form maintaining social contacts, finding a user with common interests, creating content and sharing information. Susan et al. (2018) told that the online resource called Communication Learning in Practice. It can provide to successfully integrate the teaching and learning of a complex set of tacitly.

It also provides a flexible way for academics, and students. The repeated use of Communication and learning by students and academics indicate that the resource and its delivery model are considered useful, respected, and impactful the intended audiences. Zekai et al. (2016) study that the monitoring developments in the internal and external environmental conditions of business, gaining the necessary skill is critical. The skills are trained in strategic management course in the university. Nikolas et al. (2015) study that web conference teaching is becoming more common. Cheng \& Min (2017) found that ten motivational factors in learning are as follow: interest, desire, fellowship, communication, instrumental value, perspective, the personality of the teacher, class time, method of teaching, and curriculum. Rojan (2016), study that the services of quality are positively related to student satisfaction. In this competitive management education, schools must focus on managing, and enhancing service quality to make students happy.

\section{Methodology of Research}

This study was qualitative research. In-depth interview (Individual interview) of thirty bachelor degree people which three people from each district in Chonburi province, Thailand. The four following questions were asked the participants.

Question1: Can you describe the benefit of the online business program, and On Campus program?

Question2: Can you describe the work, learning, and life balance for deciding to apply for the Online or OnCampus graduate business program.

Question 3: Can you explain the expectation of Online, and On-Campus business program to advance in your job career?

Question 4: Can you describe the disadvantage of the online business program and on-campus program? 
Question 5: The cost of On-Campus and Online programs affect the decision to study?

Data Analysis: The study use content analysis, and t-test of SPSS19 to explain the compare means of data.

\section{Results of Research}

General information of participant is thirty people with age between 21-50 years old, and graduate bachelor degree.

Table 1: Perception of Thai Students on Graduate Business Program Comparison between Online and On-Campus Program

\begin{tabular}{lccccc}
\hline Program & Number (person) & Mean & SD & t-test & Significance \\
\hline On-Campus & 21 & 3.3333 & 0.1054 & 0.592 & 0.559 \\
Online & 9 & 3.2222 & 0.1470 & & \\
\hline
\end{tabular}

The perception of Thai students on the graduate business program was not different between Online and OnCampus program. The seventy percent of participants (21 persons) decision to apply On -Campus graduate business program, and thirty percent of participants ( 9 persons) decision to apply for the online graduate business program.

\section{The Benefit and Disadvantage of on-campus and Online Program}

- The benefit of the On-Campus program, the students, have a strong relationship, the connection among students more than the online graduate business program. Students can interact with friends and professor. Students have alumni, and community in the building. On-Campus program give the educational experience, communications skill meeting, enhance leadership and quantitative skill (76.67 percent of participants)

- The advantage of On-campus programs, students can get the tone of voice of lecturer, (13.33 percent of participants) get eye contact (10 percent of participants, ask the lecturer or professor immediately (23.33 percent of participants). The career counselling is available in class (36.67 percent of participants).

- On-campus students cannot skip classes and on time learning (53.33 percent of participants).

- Disadvantage of On-Campus program is waste time to travelling (100 percent of participants).

- The thirty percent of participant decision to apply for online graduate business program.

- The benefit of an online program, the students have the opportunity to plan the convenient time for learning, working, hobby, family life, and work the current job during learning (100 percent of participants).

- Online programs have less time for boarding time. Online programs have cheaper expense more than On-Campus (100percent of participants). The expense is course materials (textbooks and documents) and transport cost (26.67 percent of participants).

- Disadvantage of Online program is inconvenient to get library service in books, journal, and the service cannot available after working hours (33.33 percent of participants).

- The cost of On-Campus or Online program affects the decision to study (13.33 percent of participants).

\section{Conclusion}

The advantage of online graduate business programs, the student can learn, and make quiz 24 hours. If a student has the question, they can ask the professor immediately, the students convenient to manage the time for learning, working, family more than On-Campus graduate business program. The career advancement of online business program is growth your 0career and develops the business knowledge (73.33 percent of participants). The disadvantage of Online graduate business program, students, have not connected among 0business man because of 0learning with 000smart phone, PC computer and tablet. The decision making of students to apply for the On-Campus program more than an online program are 40 percent. The career 
advancement of study On-Campus programs are advancing your current position, the source of competitive advantage, increase management skill, and start students' own business (73.33 percent).

\section{Discussion}

Students want to learn in the English language of both Online and On-Campus program (43.33 percent of participants) because students want to advance in job application more than in Thai language program. Students can check course accredit of the degree and certificate from the office of Civil Service Commission, Thailand or ask the information from universities before deciding to apply for the Online or On-Campus graduate business program. The researcher has further research to interview the opinion of a human resource officer for job employment's policy to Online, and On-Campus graduate business program in Thailand.

Recommendations: Both Online and On-campus advance job career in knowledge, high position, and increase salary (83.33 percent of participants). The progress in job, salary, promote the position depend on individual performance and graduate in departments of the program such as accountancy, commerce, management, marketing and finance.

\section{References}

Cheng, L. \& Min, K. (2017). The motivation for learning Korean among Taiwanese. Ecoforum, 6(3), 1-8.

Elena, V. \& Ioana, C. (2015). Facebook Usage as Social Screening Exploring the Approach of Admission Officers from Management Colleges. Management Dynamics in the Knowledge Economy, 3(1), 61-77.

Ismail, P. \& Omer, S. (2014). Consideration for Task Analysis Methods and Rapid E-learning Development Techniques. Asia Pacific Journal of Multidisciplinary Research, 2(1), 20-24.

Maija, A., Xiaomeng, W. \& Julia, H. (2016). Relevancy of the massive open Online course (MOOC) about sustainable energy for adolescents. Education Science, 6(40), 1-11.

Miri, B., Rania, F. \& Yehudit, D. (2016). On-Campus or Online: examining self-regulation and cognitive transfer skills in different learning settings. International Journal of Educational Technology in Higher Education, 13(35), 1-18.

Mohsen, N. \& Fatemeh, M. (2014). A framework for online social networking features. Journal Management Science Letters, 4, 1107-1116.

Muqiang, Z., Chien, C., Yenchun, W. \& Wanxing, G. (2018). The Mapping of On-Line Learning to Flipped Classroom: Small Private Online Course. Journal Sustainability, 10(748), 1-14.

Nikolaus, B., Robert, S. \& Reinhard, 0. (2015). Students' emotions for achievement and technology use in synchronous hybrid graduate programs: a control-value approach. Research in Learning Technology, 23, 1-16.

Peter, R. (2017). Creative Approaches to Teaching Graduate Research Methods Workshops. Nordic Journal of information literacy in higher education, 9(1), 21-36.

Rojan, B. (2016). Relationship between Perception of Service Quality and Students' Satisfaction -A Case Study of Management School. Journal of Education and Research, 6(2), 43-64.

Shu-Man, C., Yung-Hsiu, L., Chi-Wei, L., Her-Kun, C. \& Ping, C. (2014). Promoting Positive Psychology Using Social Networking Sites: A Study of New College Entrants on Facebook. International Journal of Environmental Research and Public Health, 11, 4652-4663.

Simin, G., Ahmad, R., Muhammad, G., Ng, R., Yao, M. \& Zhang, T. (2014). ICT integration in education: Incorporation for teaching \&learning Improvement, 2(2), 24-45.

Susan, R., James, H., Kay, C., Rhianna, P. \& Louise, K. (2018). CLIPS (Communication Learning in Practice for Scientists): A New Online Resource Leverages Assessment to Help Students and Academics Improve Science Communication. Journal of Microbiology \& Biology Education, 19(1), 1-4.

Zekai, O., Selmen, K. \& Altug, C. (2016). Students' opinions regarding strategic management course instruction in the graduate programs and their level of bringing qualified employee in business: A study at GAZI University. International Online Journal of Education and Teaching (IOJET), 3(3), 174-184. 